\title{
MODEL MANAJEMEN RESIKO PROYEK INSFRASTRUKTUR PERDESAAN DENGAN PENDEKATAN SISTEM PEMBANGUNAN BERKELANJUTAN
}

\author{
Zainuddin $^{1 *}$, Sujiat ${ }^{2}$ \\ ${ }^{*}, 2$, Fakultas Sains dan Teknik, Universitas Bojonegoro \\ *email : hq.unig@gmail.com ${ }^{1)}$
}

\begin{abstract}
In rural infrastructure project development activities, there are two major risk groups, namely internal risks, where this risk lies with the Activity Implementation Team (TPK) / LPMD, Village Local Assistants and Village Assistants. And secondly, external risks, which are under the control of the Village Head and Village Officials and the Team from the District Government who are not directly involved in development activities. This research begins with the distribution of the first questionnaire that looks for the probability value of a risk factor that occurs, while the risk is taken from the main questionnaire then a large risk is obtained, then the risk measurement stage is mapped with a risk level threshold diagram to see the risk that occurs and as a basis for risk preparation. . And the biggest risk value is 25 , rank 1 and an average of 6 and observations, from the results of the interview, it is found that the risk has not been managed maximally by the implementation team of village government / management activities, while from the district government risk management is still limited to absorption of the budget to reduce silpa, so specifically from the absorption of the ADD, DD and DHB budgets, the management is still not visible. The risk management model in this study with system dynamics using Vensim software in the initial study obtained from the Sustainable development system greatly affects the development of factors that are increasingly developing, increasing risks and improvements at the level of Management, Human Resources, Materials and Equipment, affecting the level of risk management, shown is shown in the graph before changing the SFD and after changing the SFD scenario.
\end{abstract}

Keywords: Rural Infrastructure Risks; Sustainable Development Systems; Dynamic Systems.

\section{ABSTRAK}

Dalam kegiatan pembangunan proyek Insfrastruktur Perdesaan terdapat dua kelompok besar resiko yaitu Resiko internal, dimana resiko ini ada pada Tim Pelaksana Kegiatan (TPK) / LPMD, Pendamping Lokal Desa dan Pendamping Desa. Dan yang kedua Resiko eksternal, yaitu ada pada kendali Kepala Desa dan Perangkat Desa dan Team dari Pemerintah Kabupaten yang tidak terlibat langsung dalam kegiatan pembangunan. Penelitian ini diawali dengan pembagian kuisener pertama yaitu mencari nilai probabilitas faktor resiko yang terjadi, sedangkan identifikasi resiko di ambil dari kuisioner utama kemudian didapat besar risiko, kemudian tahap pengukuran risiko dipetakan dengan diagram treshold of risk levels untuk mengetahui posisi risiko yang terjadi dan sebagai dasar dalam penyusunan pengelolaan risiko. Dan didapat nilai risiko terbesar 25, terkecil 1 dan rata-rata 6 dan dari observasi, dari hasil wawancara lapangan didapat bahwa risiko belum dikolola secara maksimal oleh tim pelaksana kegiatan ataupun pemerintah desa/pengelola, sedangkan dari Pemkab manajemen risiko pengelolaannya masih terbatas pada penyerapan anggaran untuk mengurangi silpa, jadi secara khusus selain dari penyerapan anggaran ADD, DD dan DHB masih belum tampak pengelolaannya. Model Manajemen Resiko pada penelitian ini diselesaikan dengan sistem dinamik menggunakan sofware Vensim didapat sistem pembangunan berkelanjutan sangat mempengaruhi hasil identifikasi resiko dengan semakin banyak faktor keberanjutan semakin menurun tingkat risiko dan perbaikan pada tingkat Manajemen, SDM, Material dan Peralatan, akan mempengaruhi tingkat Resiko, sebagaimana ditunjukkan dalam grafik sebelum berubahan skenario SFD dan setelah diadakan berubahan skenario SFD.

Kata Kunci: Resiko Pembangunan Insfrastruktur Perdesaan; Pembangunan Berkelanjutan; Sistem Dinamik.

\section{PENDAHULUAN}

Insfrastruktur Perdesaan merupakan merupakan nadi kegiatan pembanguanan di desa dimana dipengaruhi oleh beberapa factor diantaranya adalah regulasi baik ditingkat 
Kabupaten maupun Desa serta kurangnya pemahaman pengelola atau Tim Pengelola Kegiatan, sehingga sebagian insfrastruktur tersebut ada yang berfungsi dengan baik ada yang mangkrak seperti monument yang tidak terawat dan ada pula yang sudah tidak berfungsi, dan Resiko pembangunan perdesaan merupakan probability dari kegiatan yang kurang difahamani dalam mengelola kegiatan pembangunan didesa, kemungkinan terjadinya peristiwa yang tidak pasti, tidak terduga dan bahkan tidak diinginkan yang akan mengubah prospek probabilitas pada investasi yang diberikan (Kartam, 2001). Resiko proyek dalam manajemen resiko adalah efek kumulasi dari peluang kejadian yang tidak pasti, yang mempengaruhi sasaran dan tujuan proyek (Wideman, 1992). Oleh karena itu, resiko memainkan peran penting dalam setiap pengambilan keputusan dan dapat mempengaruhi kinerja Proyek (Wiguna dan Scott, 2005).

Faktor resiko pada proyek konstruksi dapat dibagi menjadi dua kelompok besar: resiko internal, yang jatuh dalam kendali tim pelaksana Kegiatan/LPMD. Resiko eksternal, yang meliputi unsur-unsur resiko yang tidak dalam kendali Pemerintah atau pemangku kepentingan utama (Banaitiene and Banaitis, 2012). Untuk mengetahui seberapa besar resiko dalam sebuah kegiatan atau proyek maka diperlukan manajemen resiko (Enshassi, 2008). Analisa resiko bertujuan untuk mengetahui dari awal kemungkinan kerugian dan keuntungan yang ada. Berdasarkan hal inilah maka manajemen resiko perlu dipelajari.

Selain memperhatikan resiko dan faktor resiko yang ada, menurut Purnomo (2012) untuk mencapai keberlanjutan suatu sistem dibutuhkan interaksi pihak - pihak terkait, diantaranya adalah masyarakat, penyedia jasa, pemerintah daerah dan pemerintah pusat secara terpadu yang merupakan suatu proses koordinasi dalam pengembangan dan pengelolaan seluruh sumber daya yang ada untuk mendapatkan manfaat ekonomi dan kesejahteraan sosial yang seimbang tanpa meninggalkan keberlanjutan ekosistem.

Sistem dinamik merupakan metode yang terbukti efektif untuk pemodelan dan menganalisis variabel yang kompleks, dinamis dan berinteraksi non linear. Metode ini dapat memberikan referensi untuk pembuat keputusan jika ingin meningkatkan keberlanjutan proyek. Studi ini memberikan alternatif Pendekatan untuk meningkatkan kesinambungan, membuat-kontribusi yang berguna untuk mempromosikan prinsip-prinsip pembangunan berkelanjutan. Namun dalam hal ini dibutuhkan data yang sangat komplek sehingga simulasi dapat dilakukan dengan optimal (Dudley, 2007; Zhang et al, 2013)

\section{METODOLOGI}

Sesuai dengan definisinya, kerangka penelitian merupakan tahapan pengumpulan dan analisis data yang relevan dan terintegrasi sesuai dengan objek penelitian (Gurning, 2011; Gable 1994; Hitt et al. 1998; Lakshman et al. 2000; Zikmund 2007; Ketchen et al. 2008; MacDonald 2008; Jarzemskiene 2009). Kerangka penelitian juga dikenal sebagai perencanaan dari pengumpulan dan analisis data yang dimaksudkan untuk mencapai tujuan dari sebuah penelitian. Pengumpulan dan analisis data diperoleh dengan berbagai cara seperti metode exploratory, studi kasus, pengalaman, survei dan kuisioner.

Penelitian ini berorientasi pada metode eksplanasi yang mengungkapkan hubungan antara dua atau lebih konsep atau variabel dari suatu fenomena (Fauzi, 2009). Secara umum, metodologi yang digunakan adalah menggabungkan antara penelitian kualitatif dengan penelitian kuantitatif yang menggunakan pendekatan studi kasus dan survei.

Tahapan dalam Penelitian ini di laksanakan dalam 4 (empat) tahapan secara sekuensi eksplanasi. Tahap Pertama ; Menganalisis Variabel Resiko Proyek Insfrastruktur perdesaan, Tahap Kedua ; Menganalisis Variabel Keberlanjutan Proyek Insfrastruktur perdesaan, Tahap Ketiga ; Konseptualisasi Model Manajemen Resiko, Menentukan Persamaan Manajemen Resiko dengan konsep sistem Pembangunan Insfrastruktur Perdesaan Berkelanjutan, Tahap Keempat ; Menganalisis dan hasil Simulasi Model Manajemen Resiko Proyek Insfrastruktur perdesaan dengan sistem Pembangunan Berkelanjutan. Adapun Bagan Alir dan tahapan penelitian ini dapat diilustrasikan dalam Gambar 1 dan 2, sedangkan berikut. 


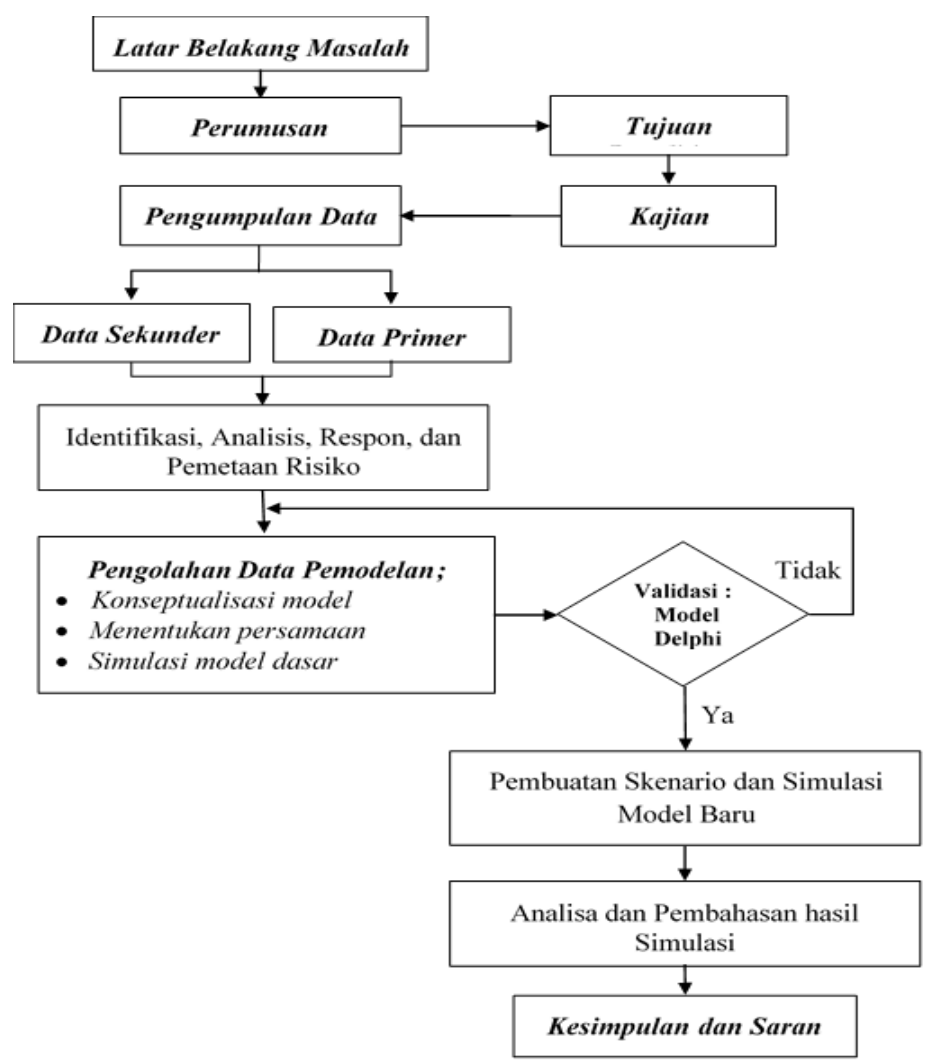

Gambar 1. Bagan Alir Rencana Penelitian

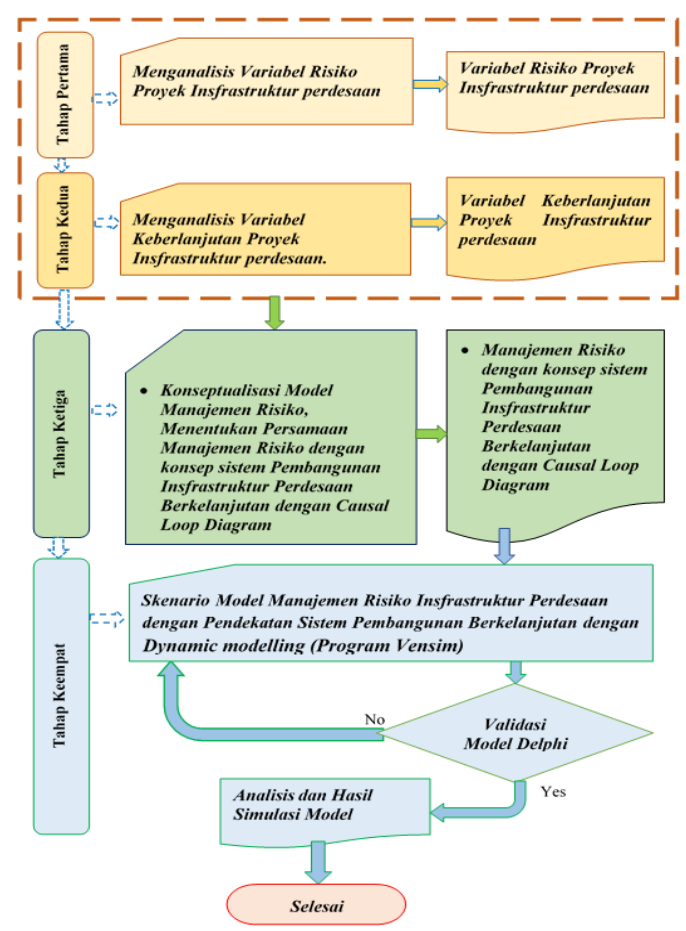

Gambar 2. Rencana Tahapan Penelitian 


\section{Identifikasi Resiko Insfrastruktur Perdesaan}

Identifikasi awal dalam penelitian ini didapatkan dari hasil diskusi / interview terhadap pelaku program terlebih dahulu, selanjutnya dipadukan dengan hasil diskusi/interview dengan stakeholders lainnya. Adapun hasil diskusi/ interview tersebut diperoleh data identifikasi awal seperti pada Gambar 3 sampai 8.

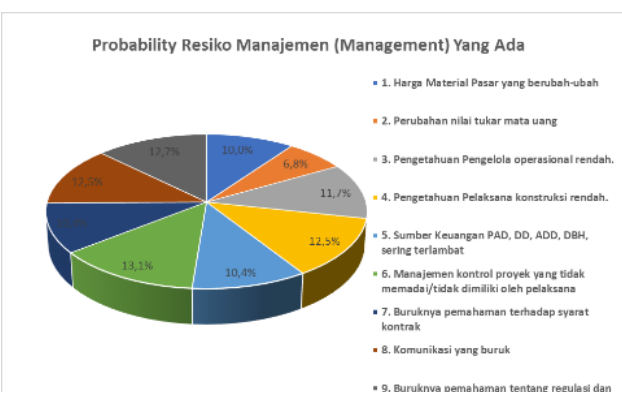

Gambar 3. Diagram Probability tahap Manajemen

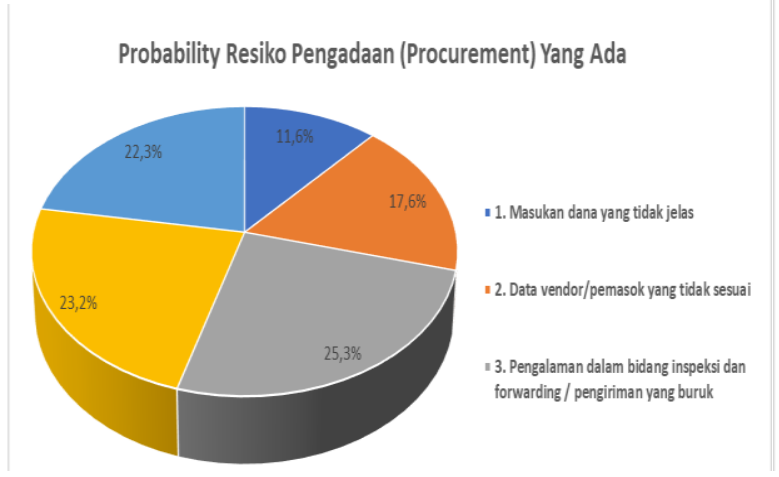

Gambar 5. Diagram Probability tahap Pengadaan

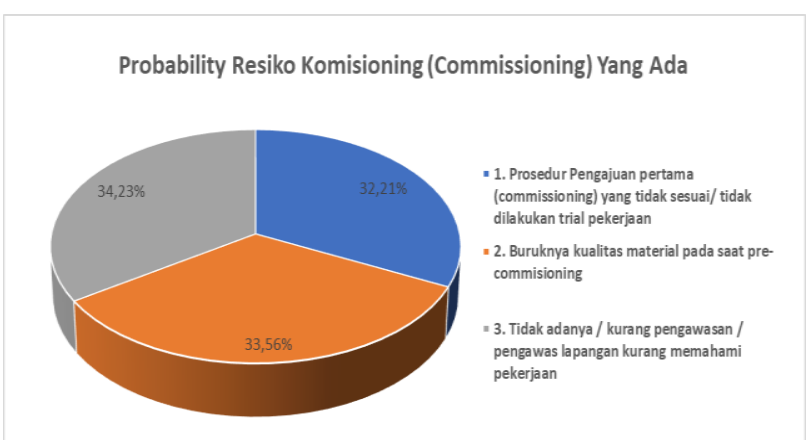

Gambar 7. Diagram Probability tahap Komisioning

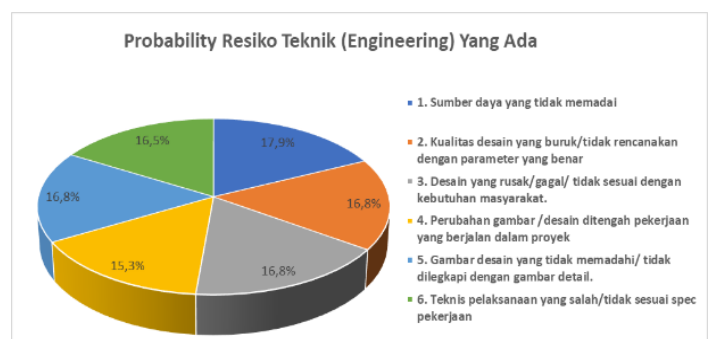

Gambar 4. Diagram Probability tahap Teknik

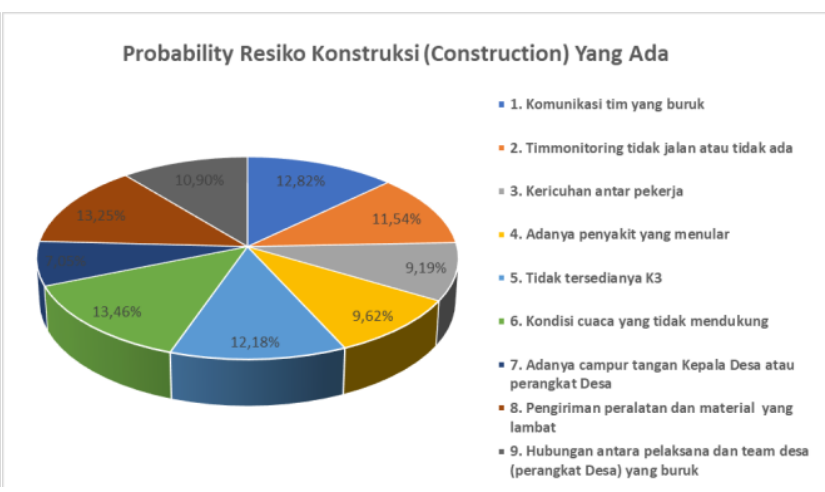

Gambar 6. Diagram Probability tahap Konstruksi

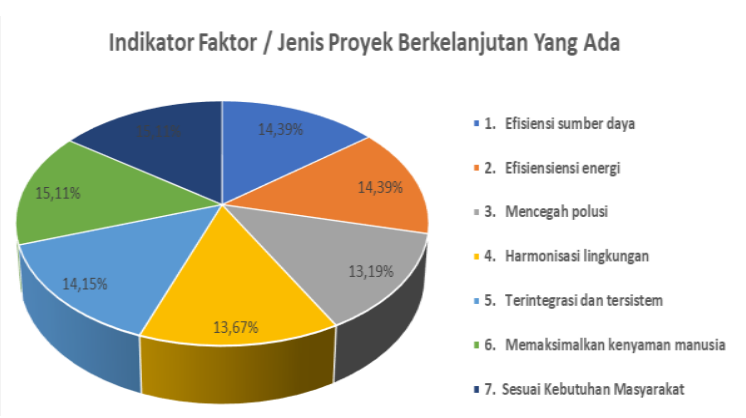

Gambar 8. Diagram Indikator Proyek Berkelanjutan

Hasil pengolahan data tahap awal terlihat pada gambar 4.2 hingga gambar 4.6. dilakukan untuk mencari Resiko yang dominan terjadi untuk dilanjutkan dan dalam gambar diagram tersebut dapat dijelaskan bahwa setiap stakeholders memiliki persepsi yang berbeda - beda mengenai kemungkinan resiko yang bisa terjadi dalam perencanaan proyek Insfrastruktur Perdesaan.

Tahap kedua yaitu untuk mendapatkan nilai resiko dengan penyebaran kuisioner utama untuk mendapatkan nilai resiko dengan menghitung perkalian P (probabiliy) dengan I (impact) yang diperoleh dari hasil kuesioner pelaku program 
yang akan dianalisis pada masing-masing tahapan untuk diketahui tingkat rangking resikonya dan responnya. Dalam kerangka Probabilitas sebagaimana Tabel 1. di bawah :

Tabel 1. Kerangka Pengukuran Probabilitas

\begin{tabular}{ccl}
\hline \multicolumn{2}{c}{ Probabilitas } & \multicolumn{1}{c}{ Kriteria } \\
\cline { 1 - 2 } Rating & $\%$ & \\
\hline 1 & $0-10$ & Sangat tidak mungkin/hampir mustahil \\
2 & $10-30$ & Kecil kemungkinan, tapi tdk mustahil \\
3 & $30-50$ & Kemungkinan terjadi \\
4 & $50-90$ & Kemungkinan Sering terjadi \\
5 & $>90$ & Hampir pasti terjadi \\
\hline
\end{tabular}

Sumber : Penilaian Resiko dari Sistem Pengendalian Intern Pemerintah (SPIP) sesuai dengan PP No. 60 Tahun 2008

\section{Analisis Resiko}

Pada tahap ini dapat diketahui sebagaimana hasil dari kuisioner yang telah dibagikan kemudian didapat masing-masing resiko dan dirangking sebagaimana Tabel 2 di bawah ini.

Tabel 2. Rangking Resiko Proyek Insfrastruktur Perdesaan

\begin{tabular}{|c|c|c|c|}
\hline $\begin{array}{l}\text { Rang } \\
\text { king }\end{array}$ & Skor & Kode & JENIS RESIKO \\
\hline \multicolumn{4}{|c|}{ A. Manajemen (Management) } \\
\hline 1 & 13,1 & M-6 & $\begin{array}{l}\text { Manajemen kontrol proyek yang tidak memadai/tidak dimiliki oleh } \\
\text { pelaksana maupun team monitoring. }\end{array}$ \\
\hline 2 & 12,7 & M-9 & Buruknya pemahaman tentang regulasi dan hukum \\
\hline 3 & 12,5 & M-4 & Pengetahuan Pelaksana konstruksi rendah. \\
\hline 4 & 12,5 & M-8 & Komunikasi yang buruk \\
\hline 5 & 10,4 & M-5 & Sumber Keuangan PAD, DD, ADD, DBH, sering terlambat \\
\hline 6 & 10,4 & M-7 & Buruknya pemahaman terhadap syarat kontrak \\
\hline 7 & 10,4 & M-7 & Buruknya pemahaman tentang regulasi dan hukum \\
\hline 8 & 10 & M-1 & Harga Material Pasar yang berubah-ubah \\
\hline 9 & 6,8 & M-2 & Perubahan nilai tukar mata uang \\
\hline \multicolumn{4}{|c|}{ B. Teknik (Engineering) } \\
\hline 1 & 17,9 & $\mathrm{~T}-1$ & Sumber daya yang tidak memadai \\
\hline 2 & 16,8 & T-2 & $\begin{array}{l}\text { Kualitas desain yang buruk/tidak rencanakan dengan parameter yang } \\
\text { benar }\end{array}$ \\
\hline 3 & 16,8 & T-3 & Desain yang rusak/gagal/ tidak sesuai dengan kebutuhan masyarakat. \\
\hline 4 & 16,8 & T-5 & $\begin{array}{l}\text { Gambar desain yang tidak memadahi/ tidak dilegkapi dengan gambar } \\
\text { detail. }\end{array}$ \\
\hline 5 & 16,5 & T-6 & Teknis pelaksanaan yang salah/tidak sesuai spec pekerjaan \\
\hline 6 & 15,3 & T-4 & $\begin{array}{l}\text { Perubahan gambar /desain ditengah pekerjaan yang berjalan dalam } \\
\text { proyek }\end{array}$ \\
\hline \multicolumn{4}{|c|}{ C. Pengadaan (Procurement) } \\
\hline 1 & 25,3 & P-3 & $\begin{array}{l}\text { Pengalaman dalam bidang inspeksi dan forwarding / pengiriman yang } \\
\text { buruk }\end{array}$ \\
\hline 2 & 23,2 & P-4 & Data transmisi untuk vendor/pemasok tidak sempurna \\
\hline 3 & 22,3 & P-5 & $\begin{array}{l}\text { Ada masalah dalam pemilihan vendor/ pemasok/tiadak dilakukan } \\
\text { pelelangan dengan benar }\end{array}$ \\
\hline 4 & 17,6 & P-2 & Data vendor/pemasok yang tidak sesuai \\
\hline 5 & 11,6 & P-1 & Masukan dana yang tidak jelas \\
\hline
\end{tabular}


D. Konstruksi (Construction)

\begin{tabular}{|c|c|c|c|}
\hline 1 & 13,5 & $\mathrm{~K}-6$ & Kondisi cuaca yang tidak mendukung \\
\hline 2 & 13,2 & $\mathrm{~K}-8$ & Pengiriman peralatan dan material yang lambat \\
\hline 3 & 12,8 & $\mathrm{~K}-1$ & Komunikasi tim yang buruk \\
\hline 4 & 12,2 & $\mathrm{~K}-5$ & Tidak tersedianya K3 \\
\hline 5 & 11,5 & $\mathrm{~K}-2$ & Tim monitoring tidak jalan atau tidak ada. \\
\hline 6 & 10,9 & K-9 & $\begin{array}{l}\text { Hubungan antara pelaksana dan team desa (perangkat Desa) yang } \\
\text { buruk }\end{array}$ \\
\hline 7 & 9,6 & $\mathrm{~K}-4$ & Adanya penyakit yang menular \\
\hline 8 & 9,2 & $\mathrm{~K}-3$ & Kericuhan antar pekerja \\
\hline 9 & 7,1 & $\mathrm{~K}-7$ & Adanya campur tangan Kepala Desa atau perangkat Desa \\
\hline & \multicolumn{3}{|c|}{ Komisioning (Commissioning) } \\
\hline 1 & 34,2 & C-3 & $\begin{array}{l}\text { Tidak adanya / kurang pengawasan / pengawas lapangan kurang } \\
\text { memahami pekerjaan }\end{array}$ \\
\hline 2 & 33,6 & $\mathrm{C}-2$ & Buruknya kualitas material pada saat pre-commisioning \\
\hline 3 & 32,2 & $\mathrm{C}-1$ & $\begin{array}{l}\text { Prosedur Pengajuan pertama (commissioning) yang tidak sesuai/ tidak } \\
\text { dilakukan trial pekerjaan }\end{array}$ \\
\hline
\end{tabular}

Sumber: : Hasil Kuesioner, 2020

\section{Respon Resiko pada Tahap Teknik (Engineering)}

Dari hasil analisa resiko tahap teknik dalam tabel 4.2. tersebut diatas kemudian dimasukkan dalam diagram treshold of risk levels dapat diketahui respon resiko rencana sebagaimana Gambar 9 berikut.

Skala Probability

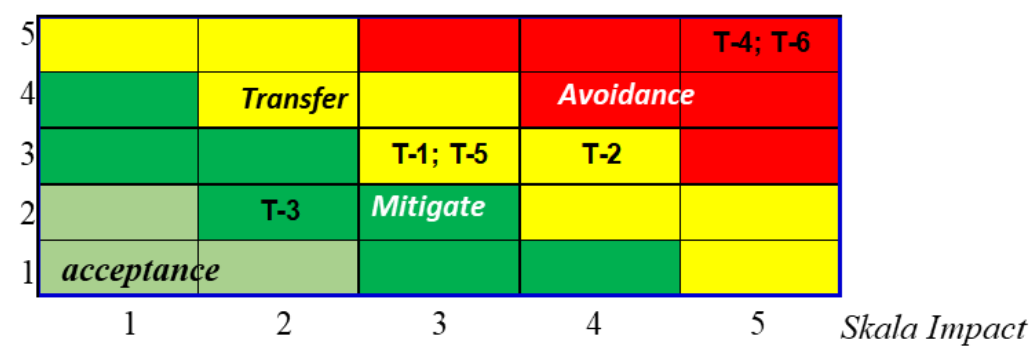

Gambar 9. Respon Resiko terhadap tahap Teknik (Engineering)

Sumber: : Hasil Kuisioner, 2020

Untuk mengetahui respon resiko secara jelas, dari Gambar 9, di atas dapat diuraikan dalam Tabel 3 berikut.

Tabel 3. Respon resiko pada tahap Teknik (Engineering)

\begin{tabular}{clll}
\hline Kode & \multicolumn{1}{c}{ Jenis resiko } & $\begin{array}{c}\text { Respon } \\
\text { resiko }\end{array}$ & \multicolumn{1}{c}{ Strategi respon resiko yang diusulkan } \\
\hline T-4 & $\begin{array}{l}\text { Perubahan gambar Avoidance } \\
\text { /desain ditengah } \\
\text { pekerjaan yang berjalan } \\
\text { dalam proyek }\end{array}$ & $\begin{array}{l}\text { Harus dilakukan koreksi desain dan gambar oleh } \\
\text { tim Kabupaten/Ahli sebelum di tetapkan untuk } \\
\text { didanai. }\end{array}$ \\
T-6 & $\begin{array}{l}\text { Teknis pelaksanaan } \\
\text { yang salah / tidak sesuai }\end{array}$ & Avoidance & $\begin{array}{l}\text { Harus dilakukan Aanwijizing oleh tim } \\
\text { Kabupaten/Ahli sebelum Pelaksanaan pekerjaan }\end{array}$ \\
T-2 & $\begin{array}{l}\text { Kualitas desain yang } \\
\text { buruk/tidak rencanakan } \\
\text { dengan parameter yang } \\
\text { benar }\end{array}$ & Transfer & $\begin{array}{l}\text { Desain / gambar harus harus mengacu pada } \\
\text { peraturan yang ada baik dalam persyaratan } \\
\text { teknis maupun spesifikasinya. }\end{array}$ \\
\hline
\end{tabular}




\begin{tabular}{|c|c|c|c|}
\hline $\mathrm{T}-1$ & $\begin{array}{l}\text { Sumber daya yang tidak } \\
\text { memadai. }\end{array}$ & Transfer & $\begin{array}{l}\text { Dalam perencanaan harus mempertimbangkan } \\
\text { Sumber daya yang ada jika tidak ada harus } \\
\text { diganti atau disesuaikan. }\end{array}$ \\
\hline $\mathrm{T}-5$ & $\begin{array}{l}\text { Gambar desain yang } \\
\text { tidak memadahi/ tidak } \\
\text { dilegkapi } \quad \text { dengan } \\
\text { gambar detail. }\end{array}$ & Transfer & $\begin{array}{l}\text { Desain / gambar harus ada gambar detail } \\
\text { dengan penjelasan yang jelas, jika tidak ada } \\
\text { maka harus diganti atau diperbaiki }\end{array}$ \\
\hline T-3 & $\begin{array}{lr}\text { Desain } & \text { yang } \\
\text { rusak/gagal/ tidak sesuai } \\
\text { dengan } & \text { kebutuhan } \\
\text { masyarakat. } & \end{array}$ & Mitigate & $\begin{array}{l}\text { Perlu ada checklist desain sebelum di tetapkan } \\
\text { atau dilaksanakan }\end{array}$ \\
\hline
\end{tabular}

\section{Respon Resiko pada Tahap Pengadaan (Procurement)}

Dari hasil analisa resiko dalam tersebut di atas didapat skor yang diperoleh dari perkalian probability dan impact yang ada dan dengan bantuan diagram treshold of risk levels dapat diketahui respon resiko rencana Insfrastruktur perdesaan pada tahap pengadaan sebagaimana Gambar 10.

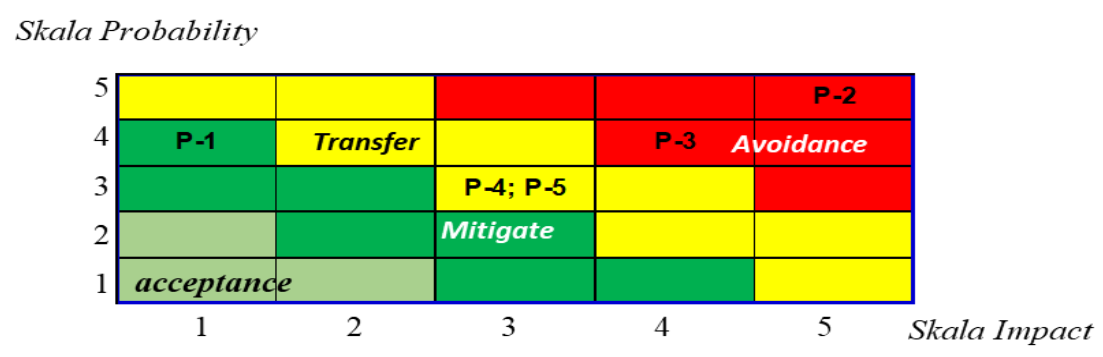

Gambar 10. Respon Resiko terhadap tahap Pengadaan (Procurement) Sumber: : Hasil Kuisioner, 2020

Untuk mengetahui respon resiko secara jelas, dari Gambar di atas dapat diuraikan dalam Tabel 4.

\section{Tabel 4. Respon Resiko pada Tahap Pengadaan (Procurement)}

\begin{tabular}{|c|c|c|c|}
\hline Kode & Jenis resiko & $\begin{array}{l}\text { Respon } \\
\text { resiko }\end{array}$ & Strategi respon resiko yang diusulkan \\
\hline $\mathrm{P}-2$ & $\begin{array}{l}\text { Data vendor/pemasok } \\
\text { yang tidak sesuai }\end{array}$ & Avoidance & $\begin{array}{l}\text { Harus dilakukan lelang barang dan alat untuk } \\
\text { memenuhi mutu material sesuai dengan } \\
\text { spesifikasi rencana. }\end{array}$ \\
\hline P-3 & $\begin{array}{l}\text { Pengalaman dalam } \\
\text { bidang inspeksi dan } \\
\text { forwarding / pengiriman } \\
\text { yang buruk }\end{array}$ & Avoidance & $\begin{array}{l}\text { Harus ada trial sehingga memudahkan dalam } \\
\text { pengambilan keputusan di tahap berikutnya. }\end{array}$ \\
\hline P-4 & $\begin{array}{l}\text { Data transmisi } \\
\text { vendor/pemasok } \\
\text { sempurna }\end{array}$ & Transfer & $\begin{array}{l}\text { Sebelum Pelaksanaan lelang harus ada } \\
\text { pengalaman atau riwayat pemasok dengan } \\
\text { alamat yang jelas }\end{array}$ \\
\hline P-5 & $\begin{array}{l}\text { Ada masalah dalam } \\
\text { pemilihan vendor/ } \\
\text { pemasok/tiadak dilakukan } \\
\text { pelelangan dengan benar }\end{array}$ & Transfer & $\begin{array}{l}\text { Dalam menentukan pemasok harus berdasarkan } \\
\text { hasil lelang atau penunjukan dengan riwayat } \\
\text { pengalaman pemasok yang jelas }\end{array}$ \\
\hline$P-1$ & $\begin{array}{l}\text { Masukan dana yang tidak } \\
\text { jelas }\end{array}$ & Mitigate & $\begin{array}{l}\text { Perlu dilakukan transparansi dalam pengelolaan } \\
\text { kegiatan. }\end{array}$ \\
\hline
\end{tabular}

Sumber: : Hasil Kuisioner, 2020

\section{Respon Resiko pada Tahap Konstruksi (Construction)}


Dari hasil analisa resiko, untuk mengatasi respon resiko pada tahap konstruksi dapat dengan bantuan diagram treshold of risk levels sehingga diketahui respon resiko rencana Insfrastruktur perdesaan pada tahap konstruksi sebagaimana Gambar 11.

\section{Skala Probability}

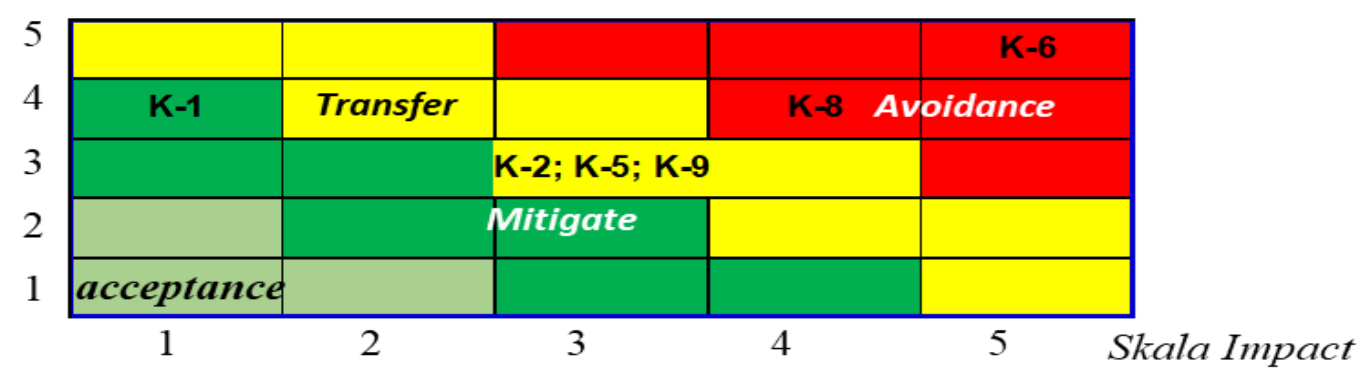

Gambar 11. Respon Resiko terhadap tahap Konstruksi (Construction) Sumber: : Hasil Kuisioner, 2020

Untuk mengetahui respon resiko secara jelas, dari Gambar 11. di atas dapat diuraikan dalam Tabel berikut:

Tabel 5. Respon Resiko pada Tahap Konstruksi (Construction)

\begin{tabular}{|c|c|c|c|}
\hline Kode & Jenis resiko & $\begin{array}{l}\text { Respon } \\
\text { resiko }\end{array}$ & Strategi respon resiko yang diusulkan \\
\hline $\mathrm{K}-6$ & $\begin{array}{l}\text { Kondisi cuaca yang tidak } \\
\text { mendukung }\end{array}$ & Avoidance & $\begin{array}{l}\text { Pekerjaan konstruksi bisa dilakukan lebih awal } \\
\text { karena biasanya anggaran turun pada } \\
\text { seperempat dan pertengahan tahun sehingga } \\
\text { perlu didata mana yang dimulai dulu sesuai } \\
\text { tingkat resiko }\end{array}$ \\
\hline $\mathrm{K}-8$ & $\begin{array}{l}\text { Pengiriman peralatan } \\
\text { dan material yang } \\
\text { lambat }\end{array}$ & Avoidance & $\begin{array}{l}\text { Harus dilakukan lelang bahan dan alat dengan } \\
\text { kontrak yang jelas dengan mencantumkan } \\
\text { klausul spesifikasi bahan dan alat serta scedule } \\
\text { pengiriman. }\end{array}$ \\
\hline $\mathrm{K}-2$ & $\begin{array}{l}\text { Timmonitoring tidak } \\
\text { jalan atau tidak ada }\end{array}$ & Transfer & $\begin{array}{l}\text { Pemerintas Desa harus memfasilitasi dibentukan } \\
\text { Tim Monitoring sesuai kebutuhan. }\end{array}$ \\
\hline $\mathrm{K}-5$ & Tidak tersedianya K3 & Transfer & $\begin{array}{l}\text { K3 harus di adakan dan dianggarkan sehingga } \\
\text { pekerja akan aman dan nyaman. }\end{array}$ \\
\hline K-9 & $\begin{array}{lr}\text { Hubungan } & \text { antara } \\
\text { pelaksana dan team } \\
\text { desa (perangkat Desa) } \\
\text { yang buruk }\end{array}$ & Transfer & $\begin{array}{l}\text { Perlu adanya rapat koordinasi yang tersusun / } \\
\text { terjadwal }\end{array}$ \\
\hline $\mathrm{K}-1$ & $\begin{array}{l}\text { Komunikasi tim yang } \\
\text { buruk }\end{array}$ & Mitigate & $\begin{array}{l}\text { Koordinasi dan transparansi perlu dilakukan } \\
\text { secara berkala }\end{array}$ \\
\hline
\end{tabular}

(Sumber: : Hasil kuesioner diolah, 2020)

\section{Respon Resiko pada Tahap Komisioning (Commissioning)}

Dari hasil analisa resiko pada tahap komisioning hanya ada dua variabel dan dengan bantuan diagram treshold of risk levels dapat diketahui respon resiko rencana Insfrastruktur perdesaan pada Gambar 12.

Skala Probability

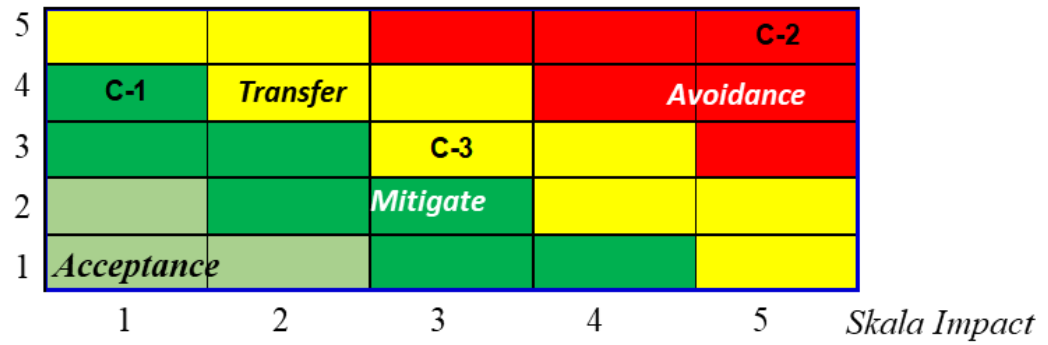


Gambar 12. Respon Resiko terhadap tahap Komisioning (Commissioning)

Sumber: : Hasil Kuisioner, 2020

Untuk mengetahui respon resiko secara jelas, dari Gambar 12 di atas dapat diuraikan dalam Tabel 6 berikut.

Tabel 6. Respon resiko pada tahap Komisioning (Commissioning)

\begin{tabular}{|c|c|c|c|}
\hline Kode & Jenis resiko & Respon & Strategi respon resiko yang diusulkan \\
\hline C-2 & $\begin{array}{l}\text { Buruknya kualitas } \\
\text { material pada saat pre- } \\
\text { commisioning }\end{array}$ & Avoidance & $\begin{array}{l}\text { Harus dilakukan trial pekerjaan untuk mengatasi } \\
\text { mutu dan pemilihan metode kerja serta pemilihan } \\
\text { alat. }\end{array}$ \\
\hline C-3 & $\begin{array}{l}\text { Tidak adanya / kurang } \\
\text { pengawasan } \\
\text { pengawas lapangan } \\
\text { kurang memahami } \\
\text { pekeriaan }\end{array}$ & Transfer & $\begin{array}{l}\text { Perlu dilibatkan tim Monitoring dan } \\
\text { Timmonitoring harus di beri bembekalan yang } \\
\text { sesuai sebelum diterjunkan / melaksanakan } \\
\text { pekerjaan }\end{array}$ \\
\hline C-1 & $\begin{array}{l}\text { Prosedur Pengajuan } \\
\text { pertama } \\
\text { (commissioning) yang } \\
\text { tidak sesuai / tidak } \\
\text { dilakukan trial pekerjaan }\end{array}$ & Mitigate & $\begin{array}{l}\text { Untuk mengatasi kualitas material dan } \\
\text { keterlambatan pekerjaan maka diperlukan trial } \\
\text { pekerjaan untuk memastikan mutu pekerjaan, } \\
\text { waktu dan biaya sesuai dengan rencana. }\end{array}$ \\
\hline
\end{tabular}

Sumber: : Hasil Kuisioner, 2020

\section{Simulasi Model}

Model dinamik Manajemen Infrastruktur Perdesaan dengan pendekatan sistem pembangunan berkelanjutan dibangun melalui logika hubungan dan interaksi antar komponen terkait. Dalam penelitian ini akan di lihat 3 (tiga) model sebagaiman Diagram Causal Loop diatas. Model diagram alir fungsi dinamik antara Biaya, Mutu dan Waktu akan dimodelkan seperti Gambar 13, 14 dan 15 di bawah ini.

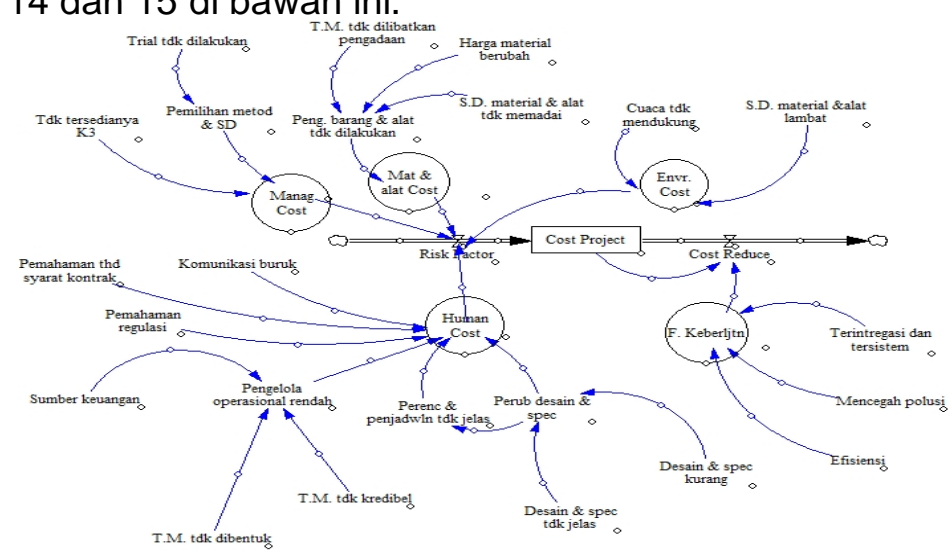

Gambar 13. Stock and Flow Diagram untuk Biaya

Sumber: : Hasil Pengolahan Data Sebab Akibat, 2020

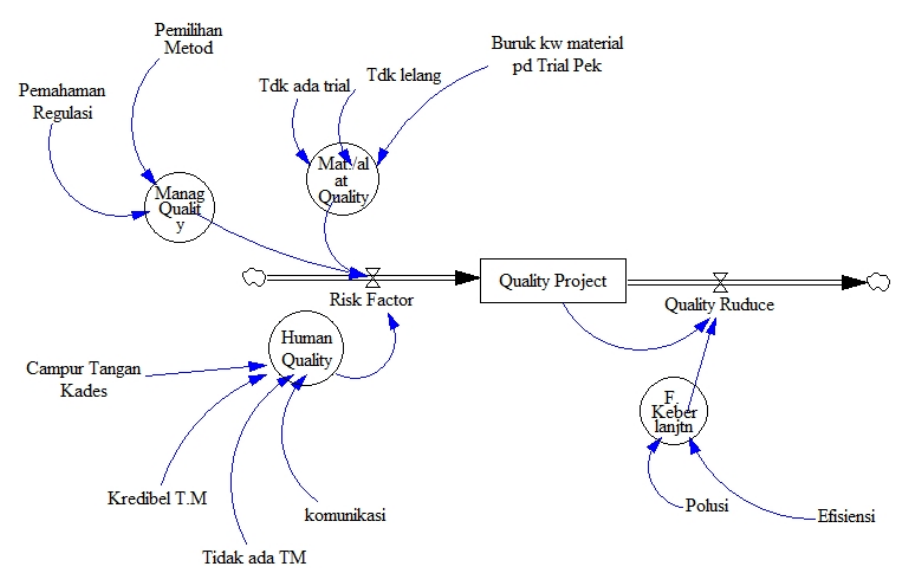


Gambar 14. Stock and Flow Diagram untuk Mutu

Sumber: : Hasil Pengolahan Data Sebab Akibat, 2020

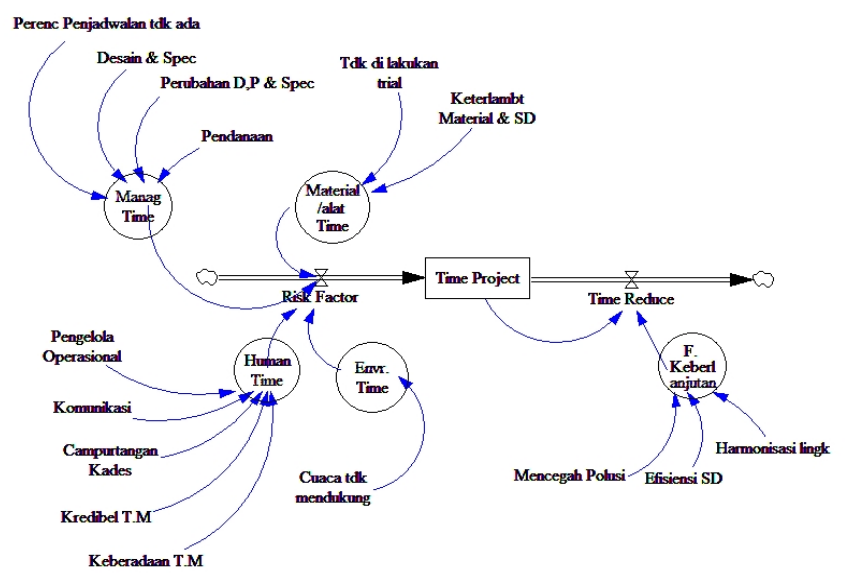

Gambar 15. Stock and Flow Diagram untuk Waktu Sumber: : Hasil Pengolahan Data Sebab Akibat, 2020

\section{Cek Model, Cek Unit dan Hasil Graph Simulasi Awal}

Untuk mengantisipasi adanya kesalahan model, maka sebelum melangkan ke tahap selanjutnya, konstruksi model harus dicek terlebih dahulu. Jika dalam model didapati telah ok maka dapat dilajutkan ke tahap selanjunya, dan jika belum maka harus melakukan konstruksi ulang hingga model benar-benar dinyatakan ok.

Dari hasil simulasi yang dibentuk pada kondisi eksisting dengan memasukkan variabel Pembangunan berkelanjutan didapat grafik datar dimana kondisi tersebut menunjukkan bahwa simulasi belum diberi tambahan variabel untuk menurunkan tingkat dan besar resiko yang diharapkan sesuai dengan waktu yang direncanakan.

\section{Pengembangan Sekenario}

Skenario Perubahan Parameter pada SFD merupakan pengembangan skenario yang diharapkan sehingga didapat bahwa penurunan besar resiko dipengaruhi terhadap faktor resiko yang didapat dari hasil identifikasi

\section{KESIMPULAN DAN SARAN}

\section{Kesimpulan}

Dari hasil Pengolahan data dari penelitian ini dapat disimpulkan sebagai berikut:

a. Resiko pembangunan Insfrastruktur perdesaan di Kabupaten Bojonegoro yang dilaksanakan secara swakelola oleh masyarakat dan Pemerintahan Desa dari hasil Identifikasi resiko masing-masing tahap mempunyai bobot besar, dan dalam diagram treshold of risk levels berada pada level Avoidance sedangkan Strategi respon resiko yang diusulkan adalah Setiap desa harus ada pendamping Lokal dan atau pendamping Desa atau kader teknik desa yang mempunyai kemampuan dan pengalaman bidang teknik sipil, Strategi respon resiko yang diusulkan adalah harus dilakukan lelang bahan dan alat 
dengan kontrak yang jelas dengan mencantumkan klausul spesifikasi bahan dan alat serta scedule pengiriman.

b. Dilihat dari tren resiko Insfrastruktur Perdesaan di Kabupaten Bojonegoro masih di dominasi oleh faktor internal yaitu lemahnya Sumberdaya manusia bidang manajemen proyek diantaranya pemahaman tentang lelang dilihat dari identifikasi resiko banyak terjadi kasus mutu material yang tidak sesuai spesifikasi dan keterlambatan material, kemudian kasus perubahan desain dan penyusunan desain \& penjadwalan proyek yang tidak tepat atau belum ada serta pemilihan metode kerja yang kurang sesuai dan sumber daya, K3 serta pelibatan tim monitoring masih banyak yang belum melakukan. Sedangkan pengaruh dari pihak eksternal yaitu masih adanya keterlambatan dana.

c. Untuk indikator keberlanjutan masalah kenyamanan manusia masih perlu diperhatikan meskipun ini sifatnya subyektif, mencegah kerusakan cagar budaya dan ekologi juga banyak yang belum difahami serta terintegrasi dan tersistemnya perencanaan pembangunan kadang juga masih dilanggar diantaranya kasus-kasus pembangunan yang muncul tanpa melalui tahap usulan gagasan dari musyawarah dusun, musyawarah desa dan musrenbang sedangkan untuk efisiensi sumber daya sudah mulai difahami dan dilaksanakan.

d. Model manajemen resiko yang diperoleh dalam penelitian ini rata-rata masih belum dikolola secara maksimal oleh pemerintah desa atau pelaksana kegiatan, sedangkan dari Pemkab manajemen resiko pengelolaannya masih terbatas pada penyerapan anggaran untuk memgurangi silpa, jadi secara khusus selain dari penyerapan anggaran ADD, DD dan DHB masih belum tampak pengelolaannya.

e. Dalam Model yang dibangun System Dynamics menunjukkan bahwa sistem pembangunan Berkelanjutan sangat mempengaruhi resiko, semakin banyak dimasukkannya faktor keberanjutan semakin menurun tingkat resiko sebagaimana ditunjukkan dalam grafik sebelum berubahan skenario SFD dan setelah diadakan berubahan skenario SFD.

f. Model yang dibangun System Dynamics dalam penelitian ini menunjukkan perbaikan pada tingkat Manajemen, SDM, Material dan Peralatan, akan mempengaruhi tingkat resiko, sebagaimana ditunjukkan dalam grafik sebelum berubahan skenario SFD dan setelah diadakan berubahan skenario SFD.

\section{Saran}

Berdasarkan hasil penelitian terdapat beberapa hal yang perlu dipertimbangkan dalam pengelolaan resiko dan model manajemen resiko proyek insfrastruktur Perdesaan yang dikerjakan secara swakelola oleh pemerintah desa selaku pelaksana dan pengawas serta pemerintah Kabupaten Bojonegoro, antara lain :

a. Perlu adanya pembinaan secara terstruktur sehingga menghasilkan pemahaman yang utuh kepada pelaku-pelaku atau pelaksana kegiatan dan operasional untuk meningkatkan kapasitasnya, sedangkan kepada pendamping baik pendamping lokal maupun pendamping desa khususnya bidang teknik untuk lebih giat dalam memotivasi pelaku desa supaya memahami tentang kegagalan sehingga menumbuhkan pentingnya manajemen resiko dalam pengelolaan pembangunan insfrastruktur perdesaan.

b. Karena masih adanya kasus pembangunan yang muncul tanpa melalui penggalian gagasan hingga pada musrenbang maka kepada Pemerintah Kabupaten untuk sering melakukan sosialisasi tentang RPJM Daerah dan RPJM Desa.

c. Pemerintah baik Daerah maupun Desa perlu adanya sosialisasi untuk penerapan sistem pembangunan berkelanjutan untuk mengurangi resiko-resiko proyek insfrastruktur perdesaan.

Untuk peneliti selanjutnya ;

a. Hendaknya dalam identifikasi di ditambahkan variabel-variabel lain yang lebih mendetail dalam kasus resiko karena rata-rata pelaku program pembangunan insfrastruktur berpendidikan setingkat SLTA dan sebagian SLTP sehingga dalam pembuatan kuisioner diperlukan bahasa yang mudah difahami. 
b. Model manajemen resiko ini akan lebih akurat jika scupnya diperkecil misalnya hanya mengamati satu desa atau satu kegiatan yang serupa dalam satu desa.

\section{DAFTAR PUSTAKA}

Abduh, Muhammad. (2007). Konstuksi Ramping Untuk Mencapai Konstruksi yang Berkelanjutan. Seminar Nasional; Sustainability Dalam Bidang Material, Rekayasa, dan Konstruksi Beton. Halaman $213-225$.

Anonimus, (2008). A Guide To The Project Management Body Of Knowledge (PMBOK GUIDE)". Fourth Edition an American National Standard. ANSI / PMI $99-001-2008$.

Anonimus, (2008). Leading Practice Sustainable Development Program For The Mining Industry (LPSDP). Risk Assessment and Management. Australian Government. Departement resources And Tourism.

Bhanthara, R., Mudjanarko, S. W., \& Moetriono, H. (2017). Study Of Factors Causing Delay Of Completion Of Construction Work Building In Airlangga University Surabaya. INSCIENTECH: Journal of Industrial, Science and Technology, 1(1), 54-70.

Boohene, R et al, (2011). Women, Livelihood and Oil and Gas Discovery in Ghana: An exploratory Study of Cape Three Points and Surrounding Communities. Journal of Sustainable Development Vol. 4, No. 3; June 2011. Pp. 185 - 195. Published by Canadian Center of Science and Education. www.ccsenet.org/jsd.

Dey, K.P. (2002). Project Risk Management: A Combined Analytic Hierarchy Process and Decision Tree Approach. Technical Article. Cost Engineering Vol. 44/No. $3 \mathrm{MARCH}$ 2002. Pp. $13-26$.

Dudley, R.G, (2007). Payments, Penalties, Payouts, and Environmental Ethics: a System Dynamics Examination. Volume 3 • Issue 2 Fall 2007. ISSN: 1548-7733 Sustainability: Science, Practice, \& Policy. Pp. 24 - 35. http://ejournal.nbii.org.

Fauzi, M. (2009). Metode Kuantitatif Sebuah Pengantar. Walisongo Press. Semarang.

Hanafi, M. M. (2009). Manajemen Resiko. UPP STIM YKPN. Yogyakarta.

Khalili, H.M dan Maleki, A. (2011). Project Risk Management Techniques in Resource Allocation, Scheduling and Planning. World Academy of Science, Engineering and Technology 59 2011. $306-310$.

Kurniawan, F., S.W. Mudjanarko, and S. Ogunlana. (2015.). Best Practice for Financial Models of PPP Projects. In Procedia Engineering, , 124-32.

Masduqi, A. (2009). Keberlanjutan Sistem Penyediaan Air Bersih Perpipaan Di Perdesaan. Program Doktor Bidang Keahlian Manajemen Dan Rekayasa Sumber Daya Air. Program Studi / Jurusan Teknik Sipil. Fakultas Teknik Sipil dan Perencanaan. Institut Sepuluh Nopember. Surabaya.

Purba, J. (2005). Pengelolaan Lingkungan Sosial. Yayasan Obor Indonesia.Jakarta.

Rosentröm, U. (2006). Exploring the Policy Use of Sustainable Development Indicators: Interviews with Finnish Politicians. The Journal of Transdisciplinary Environmental Studies, ISSN 1602-2297. Vol 5. No. 1-2. 2006. Pp. 1- 13. http://www.journal-tes.dk/.

Sastavanya, S. (2010). Penentuan Model Sistem Penyediaan Air Minum Perdesaan Yang Berkelanjutan Di Kabupaten Subang. Jurnal Perencanaan Wilayah dan Kota, Vol 21 No 2, Agustus 2010, hlm. $81-94$.

Setiawan, S. (1991). Simulasi Teknik Pemrograman dan Metode Analisis. ANDI OFFSET. YOGYAKARTA.

Singh. $\mathrm{H}$ et al, (2011). Risk Management: A Step towards Sustainable Development. IJCEM International Journal of Computational Engineering '\& Management, Vol. 13, July 2011 ISSN (Online): 2230-7893. Pp. 13 - 21. www. IJCEM.org.

Zainuddin. (2014). Analysis of Risks Factors in Highway Construction Project (Case Study : Rural Road Construction Project Bojonegoro." 